\title{
Relevance of differentiating between residential and non-residential premises for surveillance and control of Aedes aegypti in Rio de Janeiro, Brazil
}

\author{
Izabel Cristina dos Reis a,b,*, Nildimar Alves Honório ${ }^{a}$, Cláudia Torres Codeço ${ }^{c}$, \\ Mônica de Avelar Figueiredo Mafra Magalhães ${ }^{\mathrm{d}}$, Ricardo Lourenço-de-Oliveira ${ }^{\mathrm{a}}$, Christovam Barcellos ${ }^{\mathrm{d}}$ \\ a Laboratório de Transmissores de Hematozoários, Instituto Oswaldo Cruz-Fiocruz, Av. Brasil 4365, 21045-900 Rio de Janeiro, RJ, Brazil \\ ${ }^{\mathrm{b}}$ Departamento de Processamento de Imagem, Instituto Nacional de Pesquisas Espaciais, São José dos Campos, SP, Brazil \\ c Programa de Computação Científica-Fiocruz, Rio de Janeiro, RJ, Brazil \\ d Instituto de Comunicação e Informação Científica e Tecnológica em Saúde (ICICT), Fiocruz, Rio de Janeiro, RJ, Brazil
}

\section{A R T I C L E I N F O}

\section{Article history:}

Received 30 June 2009

Received in revised form

31 December 2009

Accepted 5 January 2010

Available online 13 January 2010

Keywords:

Ae. aegypti

Traps

Surveillance

Monitoring

Dengue

\begin{abstract}
A B S T R A C T
Entomological surveys on Aedes aegypti (L.) often focus on residential premises, while ignoring nonresidential premises. It has been proposed that the latter should be subject to specific monitoring strategies, since they have the potential to contribute a large proportion of the overall mosquito population. In this study, we used traps for ovipositing females to compare the levels of Ae. aegypti infestation in residential and non-residential premises and assess whether there was any evidence for a spatial association of infestation between non-residential premises and the surrounding homes. This information is important for designing specific surveillance programmes for these special sites and their surroundings. This study was conducted in three neighbourhoods of the city of Rio de Janeiro, Brazil, with distinct population densities, water services, dengue histories and vegetation coverage. Ae. aegypti abundance was measured using two types of traps (standard and sticky ovitraps) installed in five non-residential premises and 80 residential premises per neighbourhood. Mosquitoes were collected in the summer (January to March) and winter (June to September) of 2007. The distribution of captures per household per week did not differ significantly between the seasons, although larger numbers of eggs and adults were obtained during the summer. Most non-residential premises were not significantly more infested than homes, despite the larger quantities of containers. There were a few exceptions, including a transportation company, two recycling centres and a boat yard. These highly infested non-residential premises were also spatially associated with highly infested homes in the vicinity. Continuous monitoring with traps may be an effective way of evaluating non-residential premises as sources of dengue vectors for nearby communities.
\end{abstract}

(c) 2010 Elsevier B.V. All rights reserved.

\section{Introduction}

Dengue fever is one of the most important arboviruses in terms of morbidity and mortality (Gubler, 1998). In Brazil, the first dengue epidemic after the reintroduction of Aedes aegypti took place in Boa Vista, Roraima, in 1981-1982 (Osanai et al., 1983). Four years later, DENV-1 invaded and caused a large dengue epidemic in the metropolitan region of Rio de Janeiro (Schatzmayr et al., 1986), followed by a large DENV-2 epidemic in 1990 (Nogueira et al., 1990), and a large DENV-3 epidemic in 2000 (Nogueira et al., 2001; Lourenço-de-Oliveira et al., 2002). More recently, in 2008, Rio de Janeiro experienced a severe dengue epidemic, with 255,818

\footnotetext{
* Corresponding author at: Instituto Nacional de Pesquisas Espaciais (INPE), Av. dos Astronautas, 1758, Jd. da Granja, 1245-97 São José dos Campos, São Paulo, Brazil. Tel.: +55 12 39456481; fax: +55 1239456468 .

E-mail address: izareis@dpi.inpe.br (I.C. Reis).
}

reported cases and 240 deaths (SESDEC-RJ, 2008; SMS/RJ, 2008 SMS-RJ, 2008). These successive epidemics indicate how susceptible Rio de Janeiro is to the introduction and dissemination of dengue viruses (Lourenço-de-Oliveira et al., 2004b; Costa-Ribeiro et al., 2006; Honório et al., 2009a).

Ae. aegypti is considered to be the main vector for dengue viruses in Brazil (Lourenço-de-Oliveira et al., 2004a), despite the presence of Aedes albopictus. Dengue incidence and Ae. aegypti abundance follow seasonal patterns in Rio de Janeiro, with peaks during the summer when high rainfall rates and high temperatures are observed (Honório and Lourenço-de-Oliveira, 2001; Honório et al., 2009b). Ae. aegypti is a highly anthropophilic species that is well adapted to urban environments with high human population density and low vegetation coverage (Braks et al., 2003; Lima-Camara et al., 2006; Lagrotta et al., 2008; Honório et al., 2009b). In these areas, Ae. aegypti females lay eggs in artificial breeding sites such as used tyres, bottles, cans, pots, plant pots and uncovered water reservoirs containing clean or stagnant water (Christophers, 1960; Maciel-de-Freitas et al., 2007a,b). 
Water supply deficiencies have been considered to be a risk factor for Ae. aegypti proliferation, since they tend to lead people to store water in large containers (Tauil, 2001). Irregular rubbish collection is also a problem, because this leads to rubbish accumulation in vacant plots, public spaces, backyards, etc. (Tauil, 2001). The Brazilian Vector Surveillance and Control Program for Dengue and Yellow Fever considered that non-residential premises were key sites for surveillance because they tended to accumulate large quantities of potential breeding sites for Ae. aegypti, for example: used tyre dumps, scrap metal yards, cemeteries, transportation companies, bus stations, seaports and airports (SUCEN, 2002). Without adequate supervision, such non-residential premises may sustain large populations of Ae. aegypti and become important sources of adult vectors for the surrounding premises. There is still no specific legislation or surveillance practice for such areas in Brazil (Tauil, 2002).

In the present study, we compared the levels of Ae. aegypti infestation in homes and non-residential premises during two seasons (summer and winter). We also analysed whether there was any evidence for a spatial association between infestation levels in non-residential premises and the neighbouring houses. Such information is important for designing specific surveillance programmes for non-residential areas.

\section{Materials and methods}

\subsection{Study areas}

The study was carried out in three neighbourhoods in the city of Rio de Janeiro, Brazil: Higienópolis (an urban area), Tubiacanga (an urban peripheral area) and Palmares (a shantytown located in an urban peripheral area) (Fig. 1). These areas differ in terms of their human density, water and rubbish collection services, vegetation coverage and dengue history (see Honório et al., 2009b). Over the study period, the temperature varied from 24 to $28^{\circ} \mathrm{C}$ during the summer (January to March) and from 18 to $23^{\circ} \mathrm{C}$ during the winter (June to September).

Higienópolis, the urban area $\left(22^{\circ} 52^{\prime} 25^{\prime \prime} \mathrm{S}, 43^{\circ} 15^{\prime} 41^{\prime \prime} \mathrm{W}\right)$ is a neighbourhood of urban development located in the northern zone of Rio de Janeiro. It is surrounded by shantytowns and is crossed by the Yellow Line motorway. The human population density is 15,891 inhabitants $/ \mathrm{km}^{2}$. The water supply is adequate and regular, and the sewage service has high coverage. Most premises are single-storey houses with small cemented yards. The overall vegetation coverage is low.

Tubiacanga, the urban peripheral area $\left(22^{\circ} 47^{\prime} 08^{\prime \prime} \mathrm{S}, 43^{\circ} 13^{\prime} 36^{\prime \prime} \mathrm{W}\right)$ is an isolated urban peripheral neighbourhood on the Governador Island. The human population density is 8219 inhabitants $/ \mathrm{km}^{2}$. The water supply is irregular and many residents have cisterns or drums for water storage. On the other hand, the sewage service has high coverage. Most homes are single-storey houses with large backyards. In contrast with Higienópolis, the yards and streets are not paved. The vegetation coverage is moderately high.

Palmares, the urban peripheral shantytown $\left(22^{\circ} 59^{\prime} 26^{\prime \prime} \mathrm{S}\right.$, $43^{\circ} 27^{\prime} 36^{\prime \prime} \mathrm{W}$ ) is a recently settled shantytown located between a rainforest-covered mountain range and a polluted river, on one of the major axes of the city's western expansion. The human population density is 2733 inhabitants $/ \mathrm{km}^{2}$, living in very small unfinished houses, with no space between them. The main economic activity is material recycling, which results in large

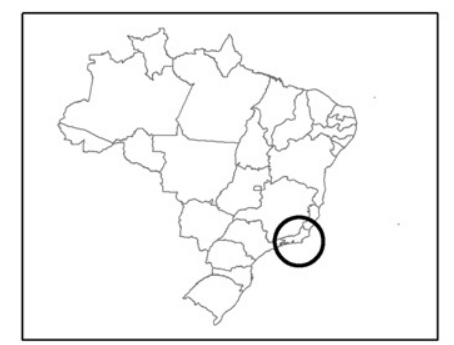

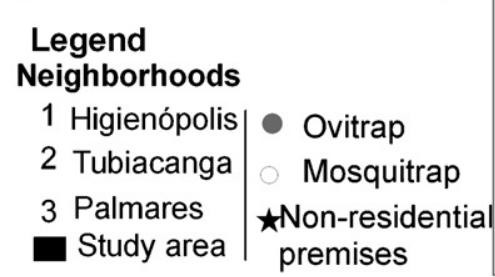

1

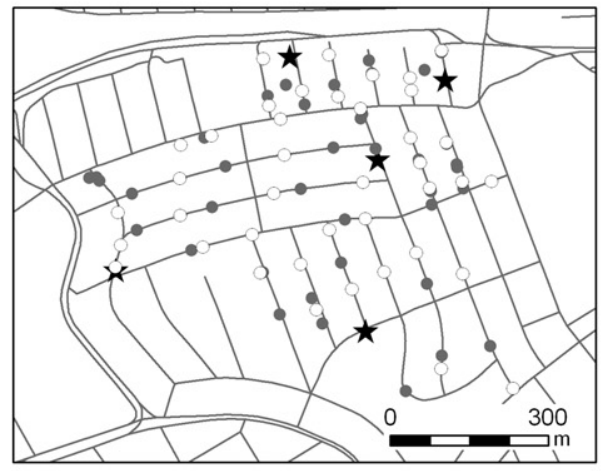

Digital map: Geoprocessing Laboratory - ICICT/ Fiocruz

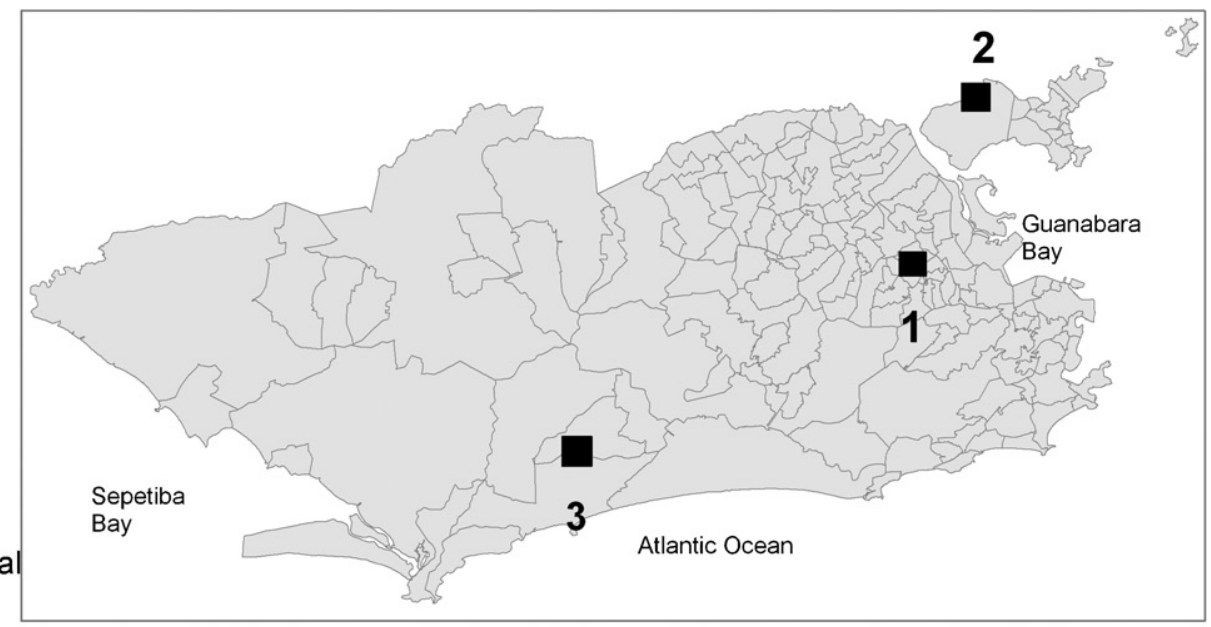

2
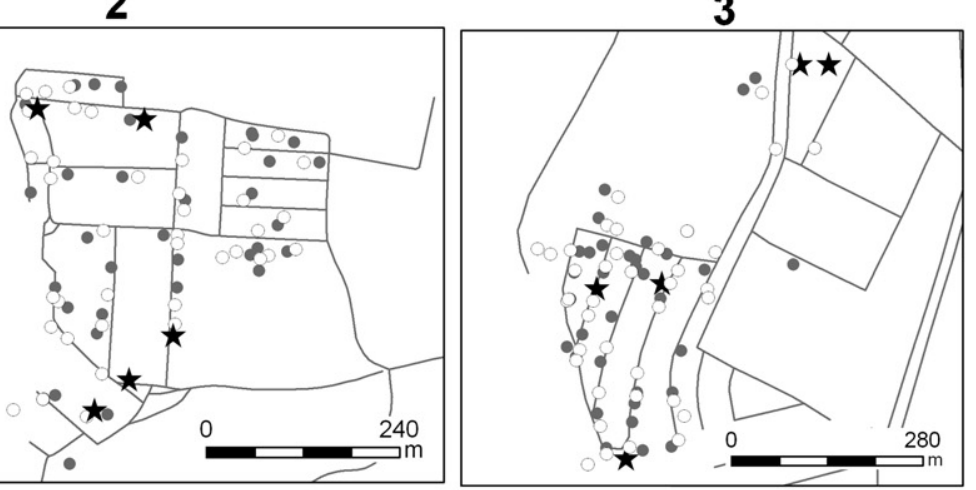

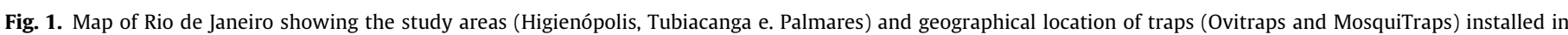
residential and non-residential premises. 
accumulations of rubbish in any open space that can be found. The water supply is irregular; there are many wells; and residents store water in barrels and buckets. Vegetation coverage is low within the shantytown and high in its surroundings.

\subsection{Entomological surveillance}

Five non-residential premises were identified in each neighbourhood: four car repair workshops $(1 \mathrm{H}, 2 \mathrm{H}, 3 \mathrm{H}$ and $4 \mathrm{H})$ and one transportation company $(5 \mathrm{H})$ in Higienópolis; two boat factories (1T and 2T), one repair shop (3T), one vacant plot (4T) and one scrap yard (5T) in Tubiacanga; and one vacant plot (1P), three recycling centres (2P, 3P and $4 \mathrm{P}$ ) and one car repair workshop (5P) in Palmares (Fig. 1). A pair of traps was installed at each of these sites: one standard ovitrap and one sticky ovitrap (MosquiTRAP, Ecovec, v.1.0). The standard ovitraps consisted of a black plastic container filled with $300 \mathrm{ml}$ of $10 \%$ diluted hay infusion and a wooden paddle for ovipositing on the wall (Fay and Eliason, 1966; Honório et al., 2003). The MosquiTRAP was a black container with an opening in the top that allowed mosquitoes to enter the trap, which contained water and an adhesive card with a volatile attractant (Eiras, 2002; Maciel-de-Freitas et al., 2008a). The traps were left in the field for 11 weeks during the summer and 14 weeks during the winter, with weekly inspections to replace the paddles and cards. These were taken to the laboratory to count and identify eggs and adults (Consoli and Lourenço-de-Oliveira, 1994) and counted.
At the same time, entomological surveillance was carried out on a sample of residential premises in the three neighbourhoods, as part of a larger longitudinal survey. This study is described in detail in Honório et al. (2009a). In summary, 40 randomly selected residential premises received ovitraps and another 40 received the sticky ovitraps. These premises were also visited weekly to replace the paddles and cards.

\subsection{Data analysis}

For each residential and non-residential premise, we calculated a mean infestation index by dividing the number of eggs (or adults) collected, by the number of weeks. From these data, we estimated the winter and summer density distributions of home infestation, using a non-parametric smoothing method (Bowman and Azzalini, 2003). We tested the hypothesis of equality using a bootstrap (library sm, R 2.9.1). We then compared the infestation rates between non-residential premises and homes, and identified those with infestation rates greater than the 90th percentile of the home infestation density distribution.

To test for associations regarding mosquito infestation between non-residential premises and surrounding premises, we took the accumulated distribution of eggs (or adults) as a function of the distance from each non-residential premise. Greater density to the left (shorter distances) would be an indication of aggregation. Significance was assessed by means of a bootstrap comparing the first

\section{Tubiacanga}

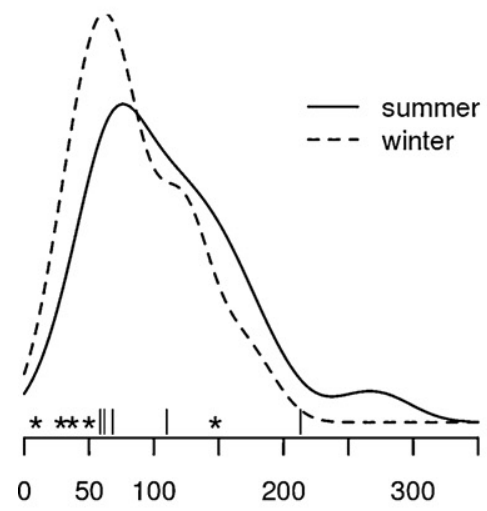

Egg density distribution

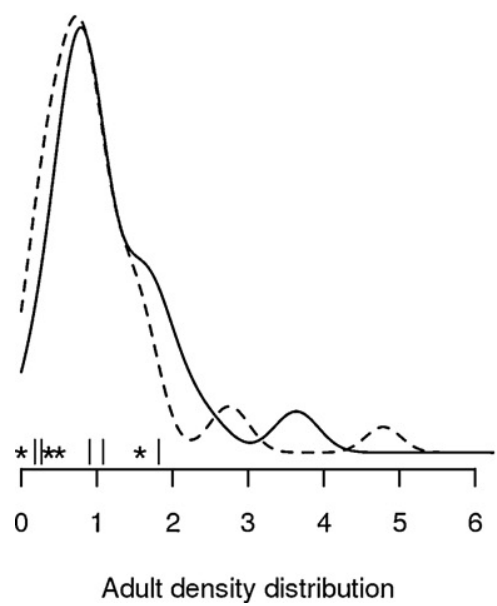

Higienópolis

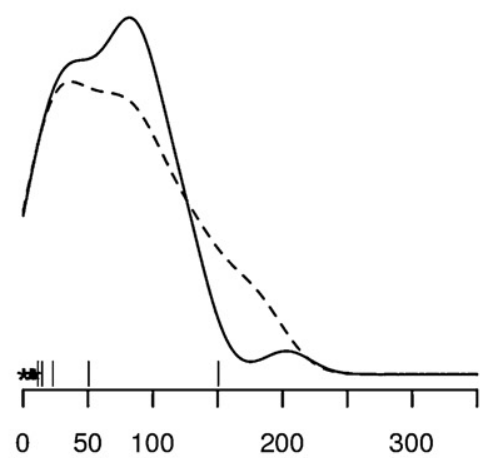

Egg density distribution

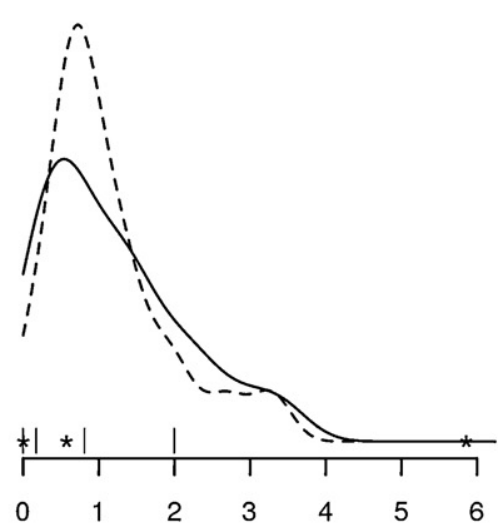

Adult density distribution
Palmares

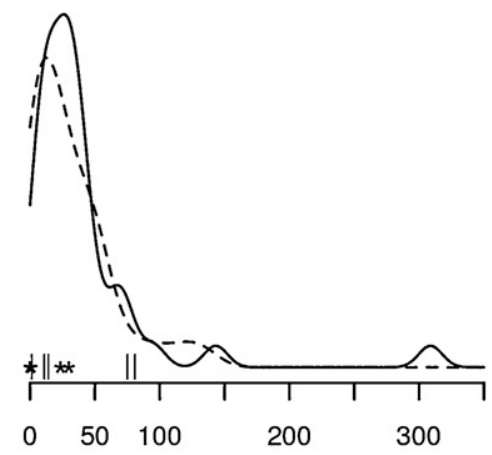

Egg density distribution

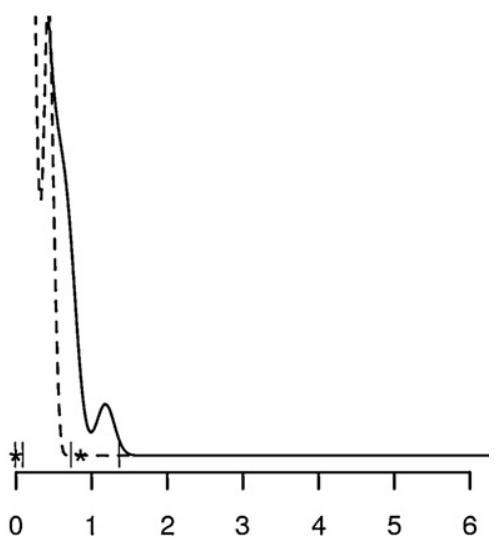

Adult density distribution

Fig. 2. Home infestation distribution of eggs and adult of Ae. aegypti. Infestation indices for the former are plotted as “" (summer) or “*” (winter). 

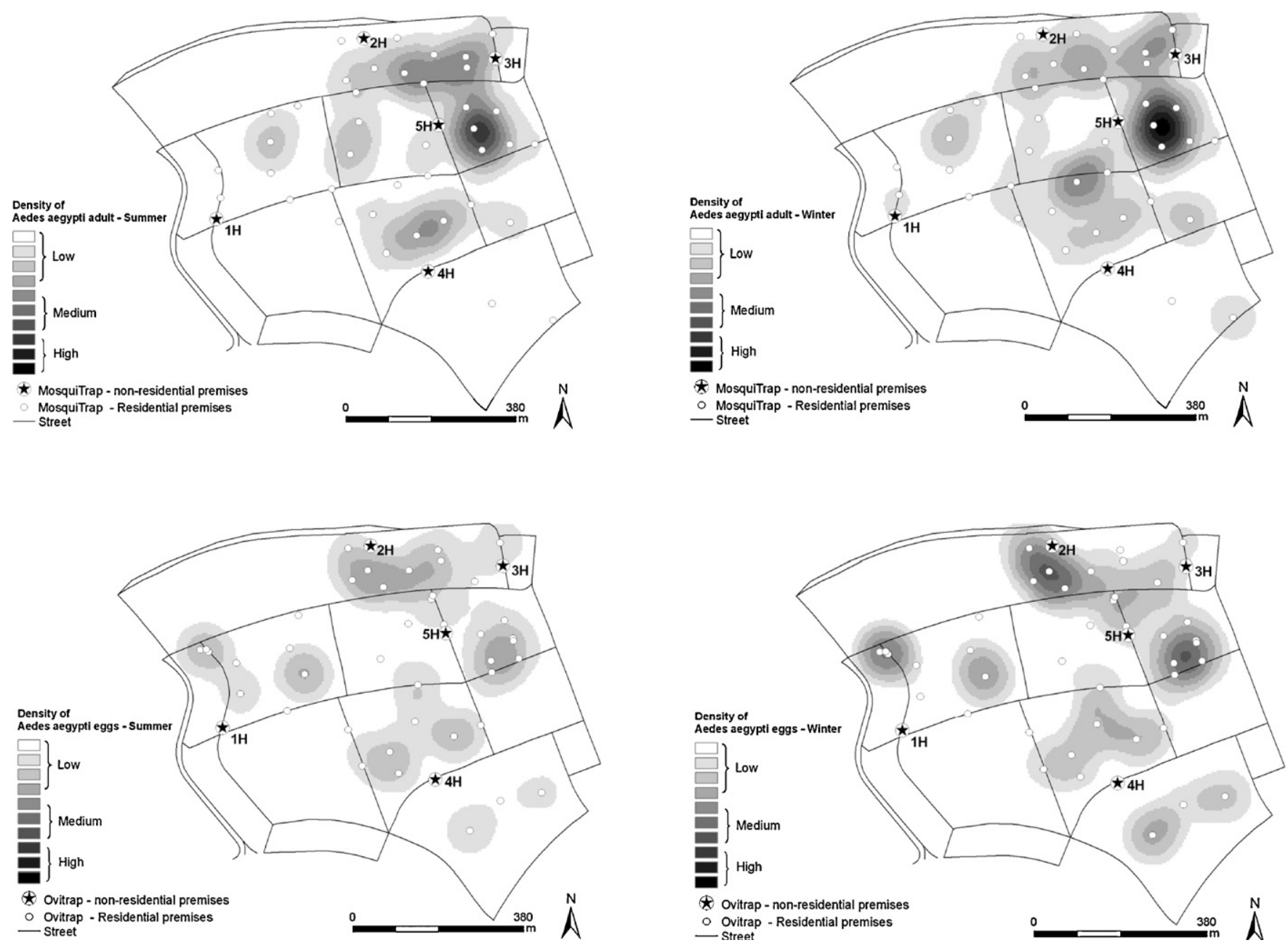

Fig. 3. Spatial distribution for eggs and adults of Ae. aegypti in residential premises during summer and winter periods of 2007 in Higienópolis, Rio de Janeiro, Brazil.

quartile of the observed distribution to that of a random distribution (Manly, 2006). Statistical analyses were performed using $R$ 2.9.1 (R Development Core Team, 2009).

\section{Results}

A total of 207,474 eggs were collected from the homes, during the summer and winter, i.e. an average of 69 eggs/home/week. Higienópolis (36.8\%) and Tubiacanga (46.3\%) accounted for the largest proportions of captures, with significantly fewer in Palmares (16.9\%). Approximately 90\% eggs were Ae. Aegypti and the remainder were Ae. albopictus. Using sticky traps, 2396 specimens of Ae. aegypti were collected from the homes, i.e. an average of 0.79 adults/home/week. Again, Higienópolis and Tubiacanga, with 47.8 and $45.0 \%$ of all captures, contrasted with Palmares, with only $7.2 \%$.

The non-residential premises yielded 16,678 eggs and 307 adult mosquitoes; 243 of them belonging to the genus Aedes (89.3\% Ae. aegypti and $10.7 \%$ Ae. albopictus). The remaining 64 were Culex quinquefasciatus. The non-residential premises produced an average of $44 \mathrm{eggs} / \mathrm{site} /$ week and 0.58 adults/site/week, and both of these rates were lower than the corresponding home measurements.

The distribution of home infestation did not differ significantly between the seasons (bootstrap $p$-value $>0.07$ for all localities and types of traps) (Fig. 2). Despite this lack of seasonal effect, we observed that the largest numbers of eggs were obtained during the summer. To compare non-residential and domicile premises, the infestation rates for the former are plotted in Fig. 2 as "|" (summer) or “*” (winter) symbols. In Higienópolis, a transportation company $(5 \mathrm{H})$ with many uncovered tyres and many small containers only partially covered under an asbestos roof showed significantly higher egg abundance than in the homes in the same area. In Palmares, where the overall infestation was low, a recycling centre (2P) was the most productive non-residential premise in terms of eggs (48.2\%), while another recycling centre (3P) was responsible for $54.8 \%$ of all adults collected in all non-residential premises in the neighbourhood. All the remaining non-residential premises showed average or low infestation, compared with domiciles.

In Higienópolis, two non-residential premises ( $2 \mathrm{H}$ and $5 \mathrm{H}$ ) were found located within mosquito infestation hotspots, both in the summer and winter (sticky ovitrap data) (Fig. 3). In Tubiacanga, there was less evidence of spatial heterogeneity of mosquito abundance, but a boat yard (1T) was found within an area with higher infestation, both in the summer and in the winter (Fig. 4). In Palmares, two of the three recycling centres (2P and 3P) were significantly close to highly infested residential premises (Fig. 5). It should be noted that all of these cited non-residential premises presented high infestation, compared with homes (Table 1).

\section{Discussion}

In this study, we investigated whether non-residential premises with high abundance of potential breeding sites differed from homes in terms of mosquito productivity. This study formed part of a larger longitudinal study to assess the temporal and spatial 

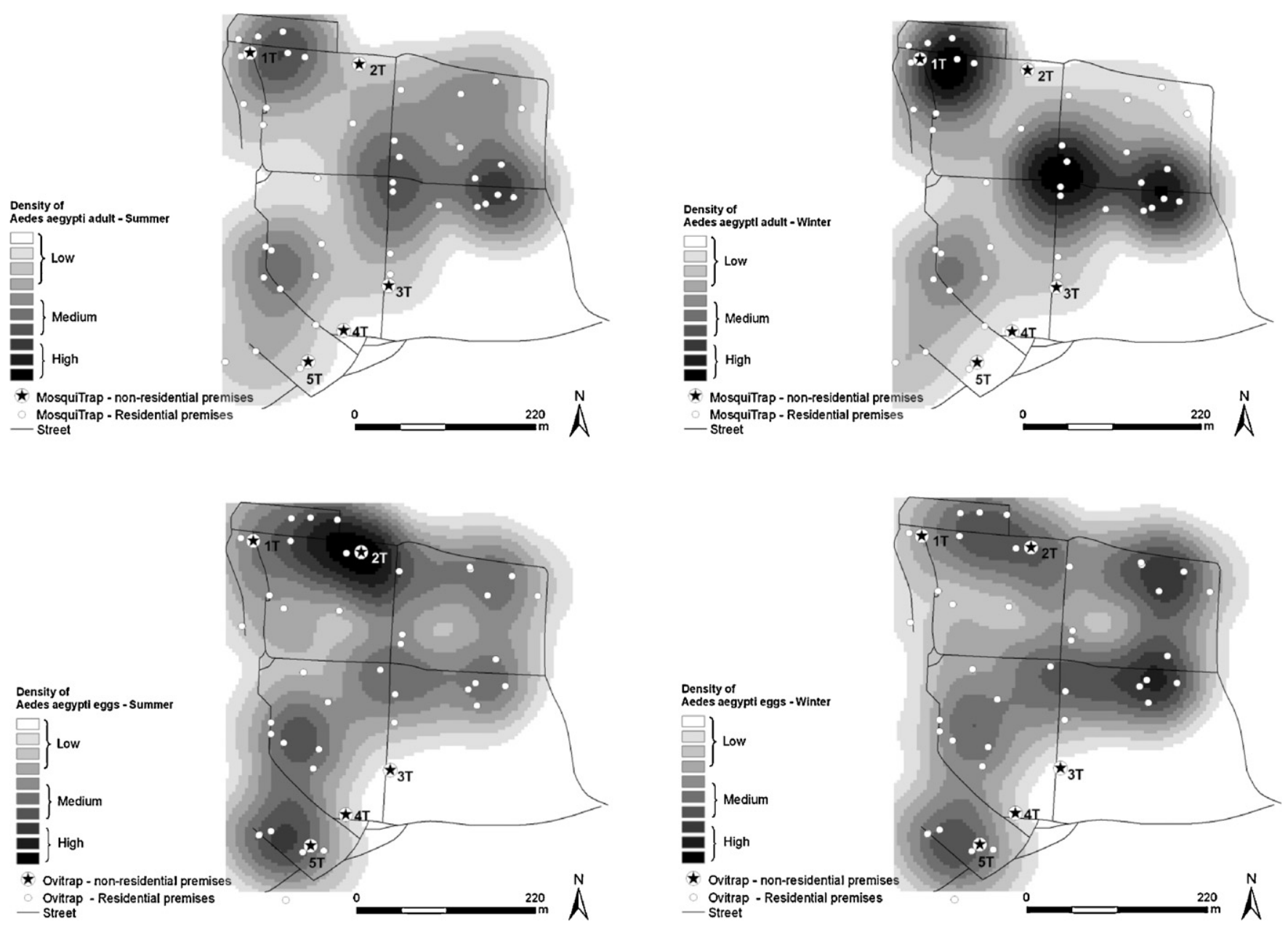

Fig. 4. Spatial distribution for eggs and adults of Ae. aegypti in residential premises during summer and winter periods of 2007 in Tubiacanga, Rio de Janeiro, Brazil.

dynamics of Ae. aegypti in Rio de Janeiro, Brazil (Honório et al., 2009a).

Many of the non-residential premises found in the study areas were repair shops. Close to the sea, boat yards were also common, and within the shantytown, recycling centres dominated. These types of sites are likely to be representative of other areas, since these are common commercial activities in urban, coastal peripheral and shantytown areas. We found that

\section{Table 1}

Aedes aegypti abundance measured by MosquiTraps (captured adults/trap week-1) and ovitraps (captured eggs/trap week-1) installed in five non-residential premises in each of the neighbourhoods-Higienópolis, Tubiacanga and Palmares, Rio de Janeiro, Brazil during the 2007 summer and winter. Stars indicate non-residential premises around which home captured eggs or adults of Ae. aegypti were found to be significantly spatially aggregated.

\begin{tabular}{|c|c|c|c|c|c|c|c|c|c|c|c|c|c|c|}
\hline \multicolumn{5}{|c|}{ Higienópolis (urban area) } & \multicolumn{5}{|c|}{ Tubiacanga (urban peripheral area) } & \multicolumn{5}{|c|}{ Palmares (urban peripheral shantytown) } \\
\hline $\begin{array}{l}\text { Non-residential } \\
\text { premises }\end{array}$ & \multicolumn{2}{|c|}{ Summer } & \multicolumn{2}{|l|}{ Winter } & $\begin{array}{l}\text { Non- } \\
\text { residential } \\
\text { premises }\end{array}$ & \multicolumn{2}{|c|}{ Summer } & \multicolumn{2}{|l|}{ Winter } & $\begin{array}{l}\text { Non- } \\
\text { residential } \\
\text { premises }\end{array}$ & \multicolumn{2}{|c|}{ Summer } & \multicolumn{2}{|l|}{ Winter } \\
\hline $\begin{array}{c}1 \mathrm{H} \text { (car repair } \\
\text { workshop) }\end{array}$ & 0.00 & 51.81 & 0.21 & 7.42 & $\begin{array}{l}\text { 1T (boat } \\
\text { factory) }\end{array}$ & 1.81 & $233.81^{*}$ & 0.35 & $171.50^{* *}$ & $\begin{array}{l}\text { 1P (vacant } \\
\text { plot) }\end{array}$ & 0.00 & 11.27 & 0.00 & 0.00 \\
\hline $\begin{array}{c}\text { 2H (car repair } \\
\text { workshop) }\end{array}$ & $2.09^{* *}$ & $11.72^{*}$ & $1.07^{* *}$ & 0.57 & $\begin{array}{l}2 \mathrm{~T} \text { (boat } \\
\text { factory) }\end{array}$ & 2.72 & 110.00 & 1.57 & 28.07 & $\begin{array}{l}\text { 2P } \\
\text { (recycling } \\
\text { centre) }\end{array}$ & $0.81^{* *}$ & 81.00 & 0.21 & $38.28^{* *}$ \\
\hline $\begin{array}{c}\text { 3H (car repair } \\
\text { workshop) }\end{array}$ & 0.27 & 23.54 & 0.07 & 5.85 & $\begin{array}{l}3 \mathrm{~T} \text { (car } \\
\text { repair } \\
\text { workshop) }\end{array}$ & 0.90 & 62.72 & 0.50 & 51.14 & $\begin{array}{l}\text { 3P } \\
\text { (recycling } \\
\text { centre) }\end{array}$ & 1.45 & $75.54^{* *}$ & 0.07 & 23.71 \\
\hline $\begin{array}{c}\text { 4H (car repair } \\
\text { workshop) }\end{array}$ & 0.00 & 15.09 & 0.00 & 0.00 & $\begin{array}{l}4 \mathrm{~T} \text { (vacant } \\
\text { plot) }\end{array}$ & 0.27 & 73.45 & 0.00 & 8.85 & $\begin{array}{l}\text { 4P } \\
\text { (recycling } \\
\text { centre) }\end{array}$ & 0.00 & 1.72 & 0.07 & 0.00 \\
\hline $\begin{array}{l}\text { 5H (transportation } \\
\text { company) }\end{array}$ & $1.36^{*}$ & 172.72 & $0.71^{* *}$ & 9.50 & $\begin{array}{l}\text { 5T (scrap } \\
\text { yard) }\end{array}$ & 1.09 & 75.09 & 0.35 & 44.78 & $\begin{array}{l}\text { 5P (car } \\
\text { repair } \\
\text { workshop) }\end{array}$ & 0.09 & 19.54 & 0.00 & 0.85 \\
\hline
\end{tabular}

\footnotetext{
${ }^{*} p<0.05$.
}

$p<0.001$ 

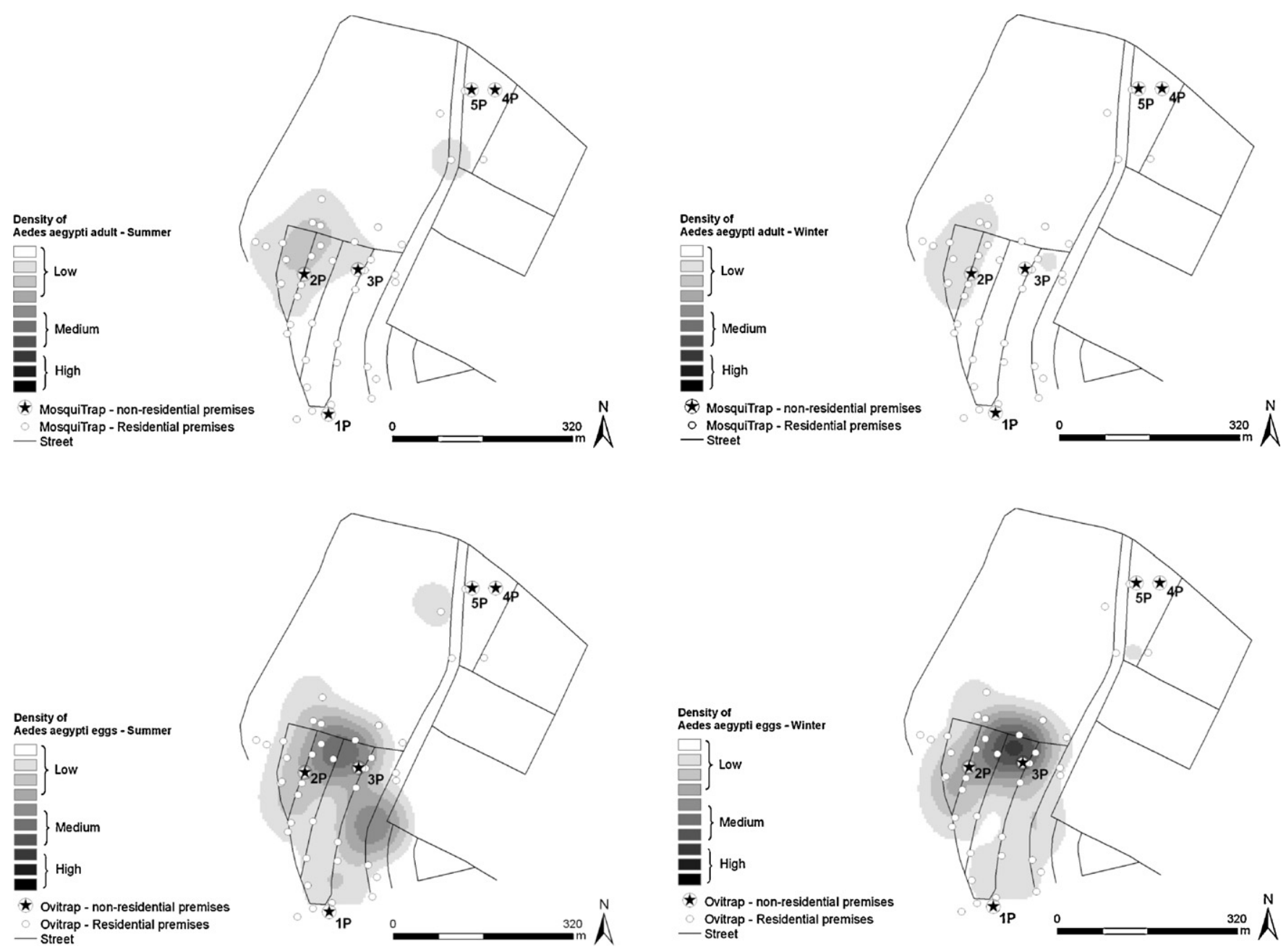

Fig. 5. Spatial distribution for eggs and adults of Ae. aegypti in residential premises during summer and winter periods of 2007 in Palmares, Rio de Janeiro, Brazil.

most of the non-residential premises were not significantly more infested than the homes were, despite the larger numbers of containers. However, there were a few exceptions. In Higienópolis, one transportation company and one car repair workshop were both highly infested and closely associated with a highly infested neighbourhood. In Palmares, two out of the three recycling centres were also highly infested, and in Tubiacanga, a boat yard was highly infested. Boats have been considered to be key breeding sites in Tubiacanga previously (Maciel-de-Freitas et al., 2007b, 2008b). Considering that most control efforts are devoted to residential premises, the occurrence of a few non-residential premises with very high infestation emphasises the importance of designing specific control and surveillance activities for these settings.

The importance of non-residential premises for mosquito proliferation has been emphasised by other authors. In the municipality of Nova Iguaçu, in the metropolitan region of Rio de Janeiro, Lagrotta et al. (2008) found that the areas that were highly infested with Ae. aegypti were also the areas with high abundance of non-residential premises (petrol stations, tyre repair shops and scrap iron containers). In Londrina, Paraná, Lopes et al. (1993) found significantly high abundance of Ae. aegypti larvae in abandoned vacant plots (Lopes et al., 1993). In São José do Rio Preto, São Paulo, Chiaravalloti-Neto (1997) identified tyre repair shops and tyre dumps, construction material storage areas and car repair workshops as important places for Ae. aegypti production. In Argentina, cemeteries were found to be important non-residential settings for Ae. aegypti control (Vezzani et al., 2001).

Our results suggest that non-residential premises are not uniformly highly productive sources of mosquitoes. However, these are sites that are often infested: they do have large numbers of potential breeding sites and they are not usually targets for vector surveillance and control. Continuous or frequent monitoring with traps may be an effective way of evaluating non-residential areas as sources of dengue vectors for nearby communities. We further suggest the use of the presented methodology (traps + mapping + non-parametric comparison of homes versus non-residential premises) to pinpoint the non-residential premises that should be subject to more detailed intervention.

\section{Acknowledgements}

The authors wish to thank Núcleo de Apoio a Vetores no Campus da Fiocruz for support for this research project. We are grateful to Maria Goreti Rosa-Freitas for the translation into English and for helpful discussions, comments and a critical review of the manuscript. We also thank the people of Tubiacanga, Higienópolis and Palmares for their collaboration. This work was supported by Fundação Oswaldo Cruz (FIOCRUZ), Fundação de Amparo à Pesquisa do Estado do Rio de Janeiro (FAPERJ), Coordenação de Aperfeiçoamento de Nível Superior (CAPES) and Conselho Nacional de Desenvolvimento Científico e Tecnológico (CNPq). 


\section{References}

Bowman, A.W., Azzalini, A., 2003. Computational aspects of nonparametric smoothing with illustrations from the sm library. Comput. Stat. Data Anal. 42, 545-560.

Braks, M.A.H., Honório, N.A., Lourenço-de-Oliveira, R., Juliano, S.A., Lounibos, L.P., 2003. Convergent habitat segregation of Aedes aegypti and Aedes albopictus (Diptera: Culicidae) in southeastern Brazil and Florida. J. Med. Entomol. 40, 785-794.

Chiaravalloti-Neto, F.C., 1997. Descrição da colonização de Aedes aegypti na região de São José do Rio Preto, São Paulo. Rev. Soc. Bras. Med. Trop. 30, 279-285.

Christophers, S.R., 1960. Aedes aegypti (L): The Yellow Fever Mosquito. Cambridge University Press, London, 739 pp.

Consoli, R.A.G.B., Lourenço-de-Oliveira, R., 1994. Principais Mosquitos de Importância Sanitária no Brasil. Editora Fiocruz, Rio de Janeiro, 225 pp.

Costa-Ribeiro, M.C.V., Lourenço-de-Oliveira, R., Failloux, A.B., 2006. Geographic and temporal genetic patterns of Aedes aegypti populations in Rio de Janeiro, Brazil. Trop. Med. Int. Health 2, 1-10.

Eiras, A.E., 2002. Armadilha para captura de mosquitos. Patente: Privilégio e Inovação. n. PI0203907-9, "Armadilha para captura de mosquitos". 05 de set de 2002 (Depósitos).

Fay, R.W., Eliason, D.A., 1966. A preferred oviposition site as a surveillence method for Aedes aegypti. Mosq. News 26, 531-535.

Gubler, D.J., 1998. Resurgent vector-borne diseases as a global health problem. Emerg. Infect. Dis. 4, 442-449.

Honório, N.A., Castro, M.G., Barros, F.S.M., Magalhães, M.A.F.M., Sabroza, P.C., 2009a. The spatial distribution of Aedes aegypti and Aedes albopictus in a transition zone, Rio de Janeiro, Brazil. Cad. Saúde Públ. 25, 1203-1214.

Honório, N.A., Codeço, C.T., Alves, F.C., Magalhães, M.A.F.M., Lourenço-de-Oliveira, R., 2009b. Temporal distribution of Aedes aegypti in different districts of Rio de Janeiro, Brazil, measured by two types of traps. J. Med. Entomol. 46, 1001-1014.

Honório, N.A., Lourenço-de-Oliveira, R., 2001. Freqüência de larvas e pupas de Aedes aegypti e Aedes albopictus em armadilhas, Brazil. Rev. Saúde Públ. 34, 385-391.

Honório, N.A., Silva, W.C., Leite, P.J., Gonçalves, J.M., Lounibos, L.P., Lourenço-deOliveira, R., 2003. Dispersal of Aedes aegypti and Aedes albopictus (Diptera: Culicidae) in an urban endemic dengue area in the state of Rio de Janeiro, Brazil. Mem. Inst. Oswaldo Cruz 98, 191-198.

Lagrotta, M.T.F., Silva, W.C., Souza-Santos, R., 2008. Identification of key areas for Aedes aegypti control through geoprocessing in Nova Iguaçu, Rio de Janeiro State, Brazil. Cad. Saúde Públ. 24, 70-80.

Lima-Camara, T., Honório, N.A., Lourenço-de-Oliveira, R., 2006. Freqüência e distribuição espacial de Aedes aegypti e Aedes albopictus (Diptera: Culicidae) em distintos ambientes no Rio de Janeiro. Cad. Saúde Públ. 22, 2079-2084.

Lopes, J., Silva, M.A.N., Borsato, A.M., Oliveira, V.D.R.B., Oliveira, F.J.A., 1993. Aedes (Stegomyia) aegypti L. e a culicideofauna associada em área urbana da região sul, Brasil. Rev. Saúde Públ. 27, 326-333.

Lourenço-de-Oliveira, R., Castro, M.G., Braks, M.A., Lounibos, L.P., 2004a. The invasion of urban forest by dengue vectors in Rio de Janeiro. J. Vector Ecol. 29, 94-100.

Lourenço-de-Oliveira, R., Honório, N.A., Castro, M.G., Schatzmayr, H.G., Miagostovich, M.P., Alves, J.C.R., Silva, W.C., Leite, P.J., Nogueira, R.M.R., 2002. Dengue virus type 3 isolation from Aedes aegypti in the municipality of Nova Iguaçu, State of Rio de Janeiro. Mem. Inst. Oswaldo Cruz 97, 799-800.

Lourenço-de-Oliveira, R., Vazeille, M., Filippis, A.M.B., Failloux, A.B., 2004b. Aedes aegypti in Brazil: genetically differentiated populations with high susceptibility to dengue and yellow fever viruses. Trans. R. Soc. Trop. Med. Hyg. 98, 43-54.

Maciel-de-Freitas, R., Codeço, C.T., Lourenço-de-Oliveira, R., 2007a. Daily survival rates and dispersal of Aedes aegypti females in Rio de Janeiro, Brazil. Am. J. Trop. Med. Hyg. 76, 659-665.

Maciel-de-Freitas, R., Marques, W.A., Peres, R.C., Cunha, S.P., Lourenço-de-Oliveira, R., 2007b. Variation in Aedes aegypti (Diptera: Culicidae) container productivity in a slum and a suburban district of Rio de Janeiro during dry and wet seasons. Mem. Inst. Oswaldo Cruz 102, 489-496.

Maciel-de-Freitas, R., Peres, R.C., Alves, F., Brandolini, M.B., 2008a. Mosquito traps designed to capture Aedes aegypti (Diptera: Culicidae) females: preliminary comparison of Adultrap, MosquiTRAP and backpack aspirator efficiency in a dengue-endemic area of Brazil. Mem. Inst. Oswaldo Cruz 103, 602-605.

Maciel-de-Freitas, R., Peres, R.C., Souza-Santos, R., Lourenço-de-Oliveira, R., 2008b. Occurrence, productivity and spatial distribution of key-premises in two dengue-endemic areas of Rio de Janeiro and their role in adult Aedes aegypti spatial infestation pattern. Trop. Med. Int. Health 13, 1488-1494.

Manly, B.F.J., 2006. Randomization, Bootstrap and Monte Carlo Methods in Biology. 3rd edition, Chapman \& Hall/CRC, 2007 (Texts in Statistical Science Series), p. 455.

Nogueira, R.M.R., Miagostovich, M.P., Filippis, A.M.B., Pereira, M.A.S., Schatzmayr, H.G., 2001. Dengue virus type 3 in Rio de Janeiro, Brazil. Mem. Inst. Oswaldo Cruz 96, 925-926.

Nogueira, R.M.R., Miagostovich, M.P., Lampe, E., Schatzmayr, H.G., 1990. Isolation of dengue virus type 2 in Rio de Janeiro. Mem. Inst. Oswaldo Cruz 85, 253.

Osanai, C.H., Travassos-da-Rosa, A.P.A., Tang, A.T., Amaral, R.S., Passos, A.D.C., Tauil, P.I., 1983. Surto de dengue em Boa Vista, Roraima. Rev. Inst. Med. Trop. 25, 53-54.

R Development Core Team, 2009. R: A Language and Environment for Statistical Computing., http://www.R-project.org.

Schatzmayr, H.G., Nogueira, R.M.R., Travassos-da-Rosa, A.P.A., 1986. An outbreak of dengue virus at Rio de Janeiro. Mem. Inst. Oswaldo Cruz 81, 245-246.

Secretaria de Defesa Civil do Rio de Janeiro (SESDEC-RJ), 2008. Ações em Saúde. Dengue. Relatório de casos de dengue. http://www.saude.rj.gov/ Docs/Acoes/dengue/Relatorio.htm.

Secretaria Municipal de Saúde do Rio de Janeiro (SMS/RJ), 2008. Casos de incidência de Dengue por bairro e mês, e por bairro e semana no Município do Rio de Janeiro. http://www. saude.rio.rj.gov.br.

Superintendência de controle de endemias (SUCEN), 2002. Normas, orientações e recomendações técnicas para a vigilância e controle de Aedes aegypti no Estado de São Paulo. Secretaria de Estado de Saúde, São Paulo.

Tauil, P.L., 2001. Urbanização e ecologia do dengue. Cad. Saúde Públ. 17, 99-102.

Tauil, P.L., 2002. Aspectos críticos do controle do dengue no Brasil. Cad Saúde Públ. $18,867-868$.

Vezzani, D., Velásquez, S.M., Soto, S., Schweigmann, N.J., 2001. Environmental characteristics of the cemeteries of Bueno Aires city (Argentina) and infestation level of Aedes aegypti (Diptera: Culicidae). Mem. Inst. Oswaldo Cruz 96, 467-471. 